(1997年5月 6 日受付・1997年 7 月 4 日受理)

\title{
各種ウェットエンド添加剤を用いて調製した デンプンパルプ含有紙の特性
}

東京大学大学院㖘学生命科学研究科 鈴木 貴 - 磯具 明 - 尾鍋史彦

\section{Properties of Handsheets Containing Starch Pulp Prepared with Various Wet-End Additives}

\author{
Takashi Suzuki, Akira Isogai and Fumihiko Onabe
}

Graduate School of Agricultural and Life Science, The University of Tokyo 1-1-1 Yayoi, Bunkyo-ku, Tokyo 113, Japan

\begin{abstract}
Handsheets were prepared from wood pulp and starch pulp in flake form with various wet-end additives, and basic properties of the handsheets were evaluated in terms of addition levels of the starch pulp. The starch pulp swollen in water by heating had a reinforcing effect on interfiber bonding between wood pulps in the handsheets, thus resulting in increases in tensile strength and folding endurance of the handsheets. Especially, the addition of the swollen starch pulp brought about a remarkable increase in folding endurance. Furthermore, the addition of polyamideamine-epichlorohydrin resin (PAE), one of the wet-strength resins, together with the swollen starch pulp had a synergistic effect on the increase in folding endurance. Although wet strength of the handsheets decreased by the addition of the starch pulp, high levels of wet strength were retained by the PAE addition. On the other hand, printing opacity and sizing degrees decreased with the starch pulp addition. However, size contents in the handsheets containing starch pulp were constant irrespective of the starch pulp additions, thus indicated that the presence of the starch pulp components in the handsheets led to the decrease in sizing degrees.
\end{abstract}

(Received 6 May, 1997 ; Accepted 4 July, 1997)

\section{1. 緒言}

デンプンはセルロース同様, グルコースのみを構成糖

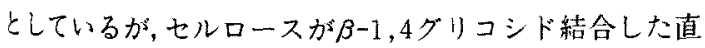
鎖状の多糖であるのに对し、デンプンは $\alpha-1,4$ 結合した螺 旋状のアミロースと分岐構造学持つアミロペクチンとの 混合物である。固体構造, 物性, 溶解性・膨潤性, 分解 性・安定性等についてのセルロースとデンプンの特性の 差異は，この結合様式の差に由来する.

デンプンは工業用材料として多方面で利用されている。 製紙産業においても，表面サイズ剤や紙力剤, 歩留り剂, 䅅工用バインダー，段ボール用接着棛等としてデンプン およびデンプン誘導体類が利用されている。その際には,
デンプンあるいはデンプン誘導体と水を加熱蒸募処理し， 水に溶解，るいははほ溶解に近い状態で利用している。 また，最近ではデンプンの生物分解性や化学加工性に注 目して，プラスチック素材としての利用の可能性が検討 されている。

一方，1980年代になり，デンプン溶液を程析によって 纎維状あるいはフレーク状に成形する技術が報告された $[1,2]$.デンプンは農業生産物であり，木材パルプの製造 方法と比較すると，機械的な処理により漂白することな くデンプン顆粒として单離することができる。したがっ て、このような観点から見れば，瀻維状に成形したデン プンは，木材パルプ繊維に一部代替可能な素材の一つに 挙げられる。そこで前報では，木材バルプの2.5 50\%を 
フレーク状のデンプンパルプに代替して手すきシートを 作製し，その基本的な力学特性を検討した(3). その絈 果, 加熱膨潤㚭理したデンプンパルプを添加して風乾し た手すきシート，あるいは加熱疆潤処理していないデン プンパルプを添加して加熱乾煤した手すきシートについ ては，耐折強さの箸しい増加や比引張強さの增加が認め られだ、デンブンパルプの添加量の增加に伴う手すき 一トの比散乱係数の低下や，シ一ト表面の電子顕微鏡観 察から，一部加熱溶融したデンブンパルプ部分が本材パ ルプ䄉維間の結合を補強することが，力学物性の向上に 起因していることが示された。

本報では，デンプンパルプを共に各種ウェットエンド 添加削を加えて調製したデンブンパルプ添加シ一トの特 性を把握することを目的としたそこで，バルプ総重量 の0ー40\%をデンプンパルプに代替し,サイズ唷拉よU゙步

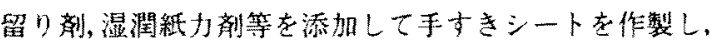
各種力学物性，サイズ特性，加熱多化特性老湘定した。

\section{2. 実験方法}

\section{1 手すきシートの調爽}

デンプンパルプ試料仗とうもるこしデンプンより調 製した緎維長が0.05-0.3mmのフレータ状デンブンパル ブを用いた (3)。その組成はデンプン30\%，硫酸アンモ 二ウム $27 \%$ ，水 $43 \%$ である，水浸清と水洗処理により， デンプンパルプ中の酼酸アンモニウムを除士し，以下の 2つの形で手すきシートの調憋に使用した。

A) 水洗しただけで加熱膨润処理なしのデンプンバル゚ (间1A)

B) 水洗後, $60^{\circ} \mathrm{C} の$ 水で20分間加熱膨潤好理したデンブ ンパルプ(国1B)

PFI ミル(実験窒用吒解穖)を用いて470CSF (カナダ標準 濾水度)に吒解しな広葉樹漂白クラフトパルプと上記Aの デンブンパルプを用い，パルブ総重量に対して、デンブ

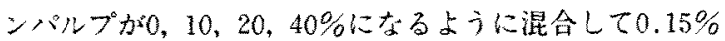
固形分濃度のパルプ等濁液を調製した。次に，サイズ剂

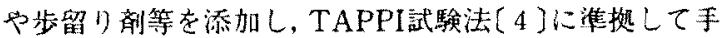
をきシートを作製した、広葉樹漂白クラフトパルプと上 記Bの加熱腤潤処理パルブ混合物から手すきシートを調 製す名際は，ウェブがワイヤ一心狙く接着して剥離でき ない場合があり，また，風乾後濾紙から剝離できない場 合があったため、デンプンパルブが0，5，10\%添加の手 寸きシートを調製した。

ウェットエンド添加凧として，アルキルケテンダイマ 一エマルション(AKD：日本PMC社製AS-202)，エマル ジョンロジンサイズ(日本PMC杜製ALー120)，ポリアミ ンアミドメピクロロヒドリン樹脂(PAE：日本PMC社製
WS-570)，硫酸アルミニウム(租光社製，16水塩として 計算したりを用いた。これらの添加削の添加量はパルプ 䈍細液中の広葉樹漂白クラフトパルプとデンプンパルプ を合わせた絶乾総重量に対する\%で表示した，調製した 手すきシ一トはプレス後， $20{ }^{\circ} \mathrm{C} ， 65 \%$ 相对鼬度下で一日 以上䑁張乾燥した。一部のシートは105足で30分間キュア リング姏理し，さらに謂湿して下記の試験に供した。

\section{2 試験方法}

手才きシートの比引㖘強さ，破断伸U゙，酎折强さにつ いては,TAPPI試験法 $(5,6)$ はしながって測定した，湿潤 引張強さは、PAEを添加したシートについて,JIS試験法 に基づいて測定した[7]。すなかち，引張試験と同様の 試駰片を 2 秒間イオン交換水に浸漬した後，新しい㵂紙

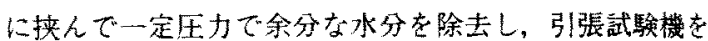
用いて測定したこの際の試験片の含水量は110-120g/ gであった。光学特性として，JIS不透明度 (8), ISOG色 度〔9]を測定した。

サイズ性については，ロジン一硫酸アルミニウム系お よびAKD-PAE系の手すきシ一トについて, JISのステ キヒトサイ乔度で評洒した[10]。また。熱分解がスク口 マトグラフィーを用いて，シート中のロジンサイス およびAKD含有量 [12]定量した。紙中のアルミニウム 含有量は，走查型電子影微鏡に付属させたエネルキー分 散型X線マイクロアナライザーにより定量した(13).

デンプンパルプ添加シートの加熱劣化特性范評洒する なめ, ロジン一硫酸アルミニウム䒺㧍よびAKD-PAE录

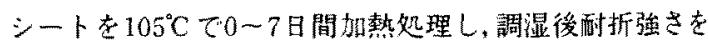
測定した。

\section{3. 結果および考察}

\section{1 力学特性}

図 1 の光学顕徵鏡写真で示す上うに，加熱膨潤処理し たデンプンパルプ Bは末処理のデンプンパルプAに比ベ て輸郭形状が不明睹になっている。すならち、デンプン Bは溶解には至っていないが，水により大去く膨潤して いる。実際の抄紙工程では，湿紙は加熱乾燥さ札るので，

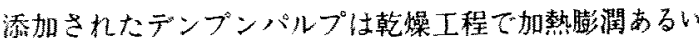
は加熱溶解の過程を経る。実験室的には、湿紙をドうム ドライヤーで乾燥させることにより，加熱乾䶂工程に対 応させることができる，しかし、デンプンパルブを添加 した湿紙を加熱乾焻した場合，木材パルプ成分当加熱乾 燥の留杽を受ける，本実験では，デンプンバルプ成分の みの膨閏性の差異によるシートの物性值を比較するなめ，

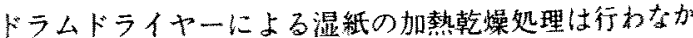
った。すなおち，未処理のデンブンパルプAと加熱膨閏 処理したデンプンバルプBを添加した湿紙を20ㄷ で乾燥 

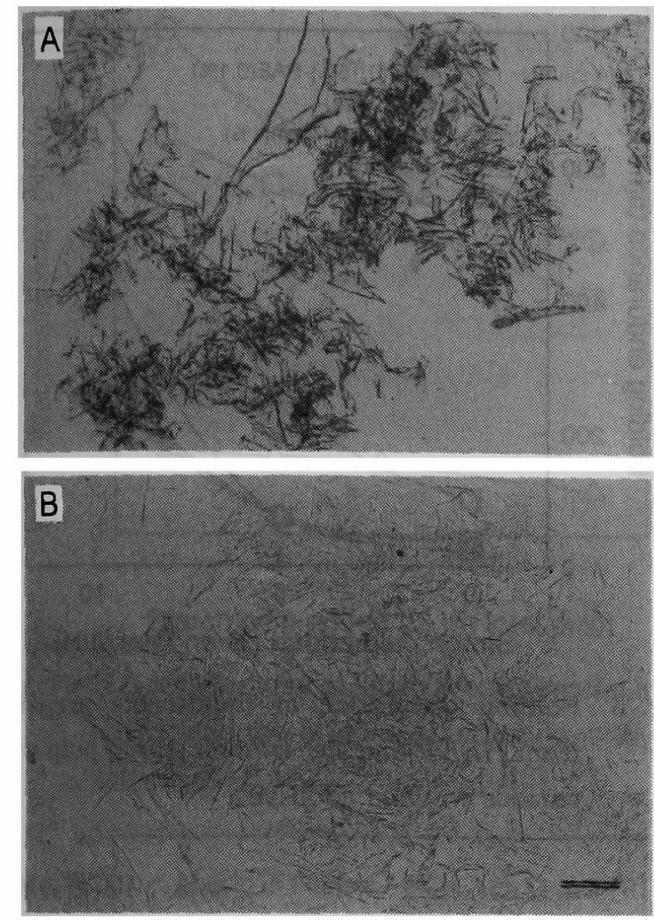

Fig. 1 Optical microphotographs of the original starch pulp (A) and that swollen in water at $60^{\circ} \mathrm{C}$ for $20 \mathrm{~min}(\mathrm{~B})$. Scale bar corresponds to $0.1 \mathrm{~mm}$.

させ，兩者の物性を比較することにより，モデル的に加 熱乾燥過程でのデンプンパルプ成分の膨潤の影響を評価 した、また，デンプンパルプ添加による坪量の変動がわ ずかであったので，以下の図ではデンプンパルプのパル プ愁濁液への添加量に対する各種物性値の変化として表 示した。

水洗のみの未処理デンプンパルプ $\mathrm{A}$ と加熱膨潤処理し たテ゚ンプンパルプ B を広葉樹漂白クラフトパルプに一部 代替してパルプ照濁液を調製し，各種ウェットエンド添 加珴を添加して作製した手すきシートの比引張強さおよ び破断伸びを図 2 , 図 3 に示す。未処理のデンプンパル プAを用いた場合（図 2)，デンプンパルプ添加量の増加 に伴って比引張強さは低下した。 デンプンパルプ添加量 の增加は, 相対的に木材パルプ含有量の低下となるが, 加熱膨潤処理を行っていないデンプンパルプAには木材 パルプの纎維間結合を補強する効果が少ないことを示し ている。湿潤紙力郕のPAEを対パルプ0.2\%添加したシー 卜は, その他のシートに比べて高い比引張強さ, 破断伸 びが見られ，キュアリング処理なしでもPAEには乾燥紙 力增強効果があることを示している。

一方，加熱膨潤処理したデンプンパルプ B 用いた場

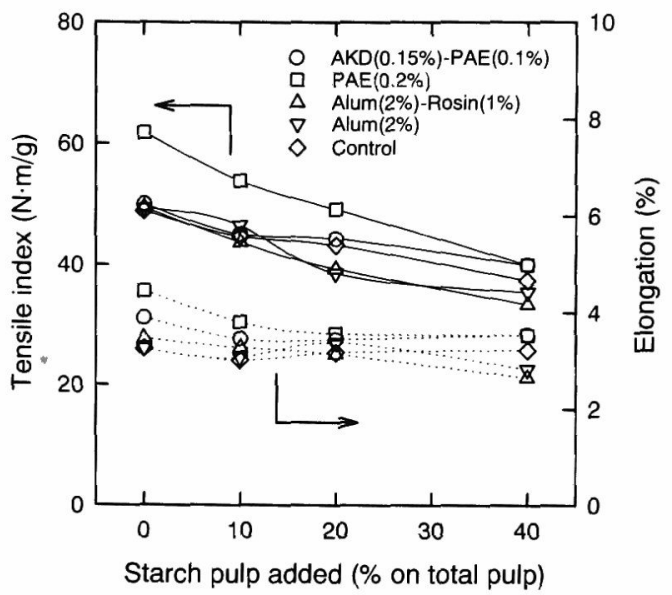

Fig. 2 Tensile index and elongation at the breaking point of handsheets prepared from hardwood bleached kraft pulp (HBKP) and the original starch pulp with various wet-end additives.

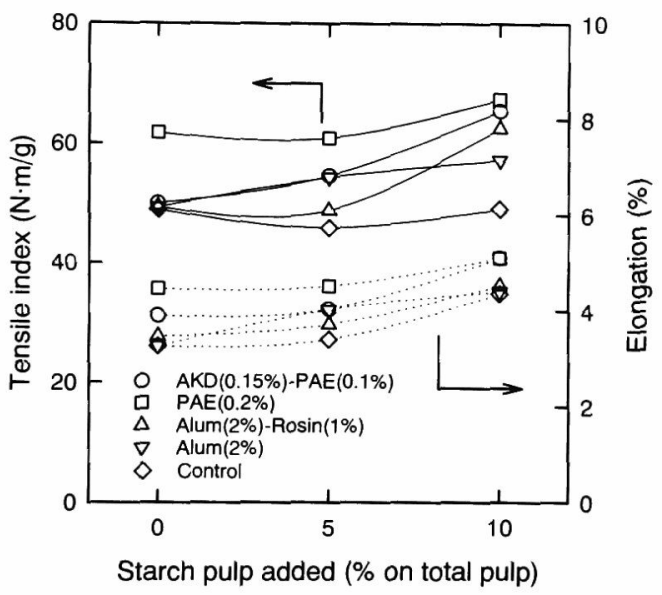

Fig. 3 Tensile index and elongation at the breaking point of handsheets prepared from HBKP and the swollen starch pulp with various wet-end additives.

合，10\%までの添加では比引張強さの低下は見られず， 同程度か増加する傾向を示した(図 3 )。 。た, 破断伸び についても増加した、デンプンパルプBの添加量の増加 により, シート中の木材パルプの重量は相対的に減少す る.したがって図 3 の結果は、デンプンパルプが加熱膨 潤状態を経ることにより, 木材パルプ繊維間の結合を補 強する効果が現われる. 加熱膨潤処理したデンプンパル プBを添加した場合でも, PAEには乾燥シート強度を増 加させる効果が認められた. 硫酸アルミニウムの添加効 果については, 一部のデンプンパルプを含むファイン成 
分の步留り量の增加とも関連しており，引張強さに与え る効果を単純に此較することはできない。

加熱膨潤処理をしていないデンプンパルプAを用いた 手すきシートの耐折強さを図4 に示す.PAEを対パルプ $0.2 \%$ 添加したジートでは, 耐折強さにおいてもPAEによ る明瞭な增強効果が認められ，きらにデンプンパルプの 添加によって增加する傾向を示した。 しかし，AKD0.15\% とともにPAEを0.1\%添加したシートおよび硫酸アルミニ ウムを添加したシートについては差唭がなく，デンプン パルプの添加に対して耐折強さは一定の值を示した。

一方，加熱膨潤処理したデンプンパルプ $\mathrm{B}$ を用いた場 合には，10\%の添加で著しい耐折強さの增加が観察され た(図 5 )。特に, PAEを0.2\%添加したシートは，キュア

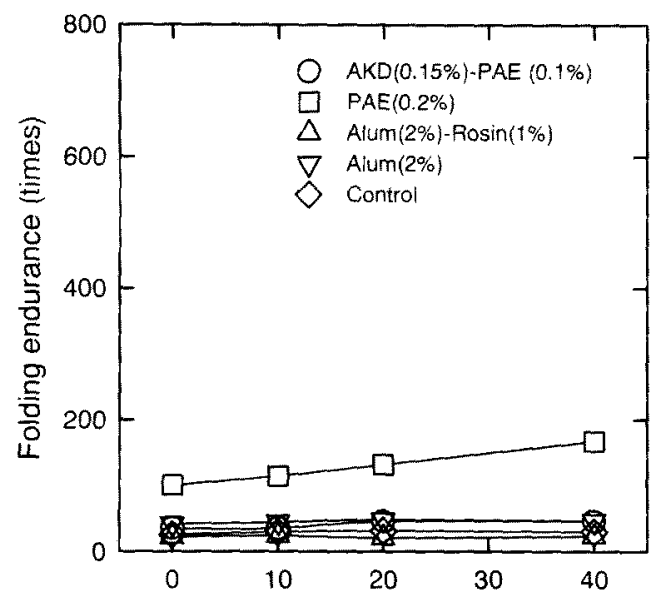

Starch pulp added ( $\%$ on total pulp)

Fig. 4 Folding endurance of handsheets prepared from HBKP and the original starch pulp with various wet-end additives.

リング処理なしでも耐折強さを增加させる効果があり， デンプンパルプBの添加による相作用により，高い耐 折強さを示した。一方，硫酸アルミニウムの添加は耐折 強さに影響を与之ない。これらの結果から，加熱膨潤処 理を経たデンプンパルプの繊維間結合補強効果は，特に 而折強さに現われる。

前述したように，加熱膨潤処理したデンプンパルプ B の添加は引張強さを低下させず，同程度かやや增加させ る結果上なった。一方，耐折強さについては著しい增加 となり，加熱膨潤処理したデンプンパルプ B 成分による， シート中の木材パルプ践維間の補強効果が特異的である ことを示している，同様の効果は，以前報告した非晶七 ルロースゲルの添加(14]扩よび再生セルロースゲルの添

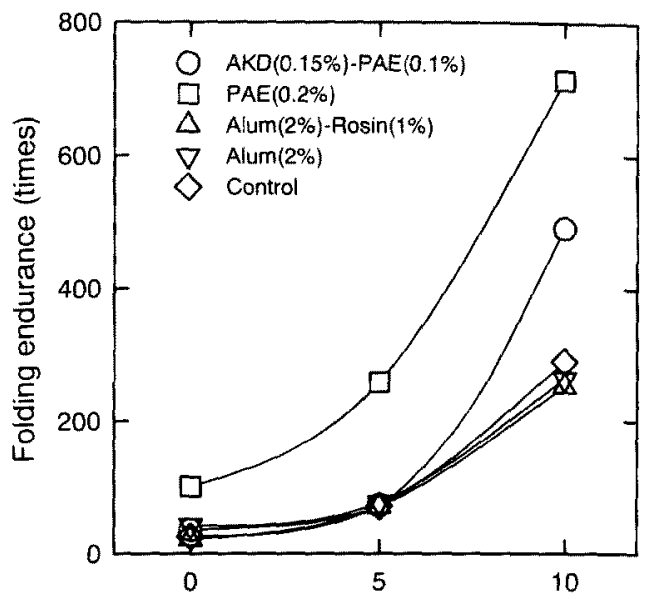

Starch pulp added (\% on total pulp)

Fig. 5 Folding endurance of handsheets prepared from HBKP and the swollen starch pulp with various wet-end additives.

加〔15]でも認められた，木材パルブ瀻維の叮解度の增加 による䋐維間結合の增加，あるいは水に溶解させた紙力 剤の添加による繊維間結合の補強作用では，引張強さお 上び预折强さともに增加させる。これらのことから，本 実験においては，加熱膨潤処理したデンプンパルプBは シ一ト内で局在化しており，乾燥によってフィルム化す

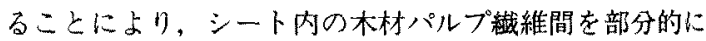
補強する作用をもつものと推定される[3]。この加熱膨 潤処理したデンプンパルプBによる瀻維間結合の部分的 な補強効果により、シート内の織維間結合の弱い部分が 反映きれる引張強さでは明瞭な増加が認められず、シー 卜内の繊維間結合の強い部分が反映される酎折強さでは 明腺な增加になったと考えられる。このようなデンプン パルプ成分のシート内での局在化住，デンプンパルプ添 加シ一トの特徴ではあるが，一方，シートの構造の不均 一性の要因にもなりうる。

図6にはデンプンパルプAを用い，PAEを0.2\%添加 して調製した手すきシートの湿潤引張強さとデンプンパ ルプAの添加量の関係を示寸. 湿潤引張強さは, PAEの 添加により顕著な增加が認められた。また，キュアリン グ処理はPAEによる湿潤引張強さの更なる增加となった。 しかし，デンプンパルプAの添加量が增加するとともに 湿潤引張強さは低下した：この傾向は図 2 の乾燥状態で の引張強さと同様である。

加熱膨潤処理したデンプンパルプ Bを用いな場合でも 同様の結果が得られ，PAE添加に上る湿潤引張強さの增 加効果，キュアリングによる更なる增加効果，デンプン パルブ添加による湿潤引張強さの低下傾向を示した(図7)。 


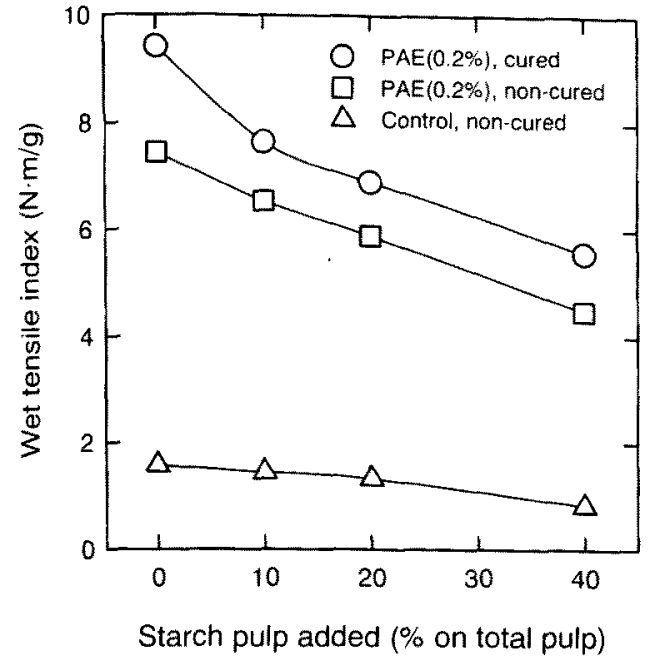

Fig. 6 Wet tensile index of handsheets prepared from HBKP and the original starch pulp with and without PAE $(0.2 \%$ on total pulp).

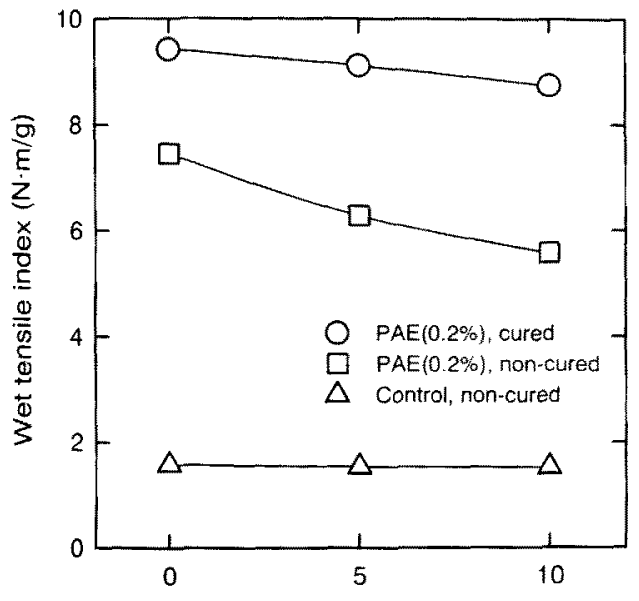

Starch pulp added ( $\%$ on total pulp)

Fig. 7 Wet tensile index of handsheets prepared from HBKP and the swollen starch pulp with and without PAE $(0.2 \%$ on total pulp).

图3の結果と比較すると、シートの水浸漬によって，デ ンプンパルプ成分の繊維間結合の補強效果が低下するこ とを示している.

以上の結果から，加熱膨潤処理したデンブンパルプ B

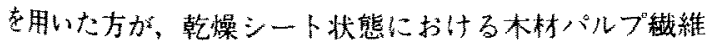
間結合の部分的な補強効果が現わ扎た。しかし，水浸漬 することにより，字の補强効果は低下する。

\section{2 光学特性}

白色度，不透明度に関しては，力学特性と異なり，デ ンプンパルプの加熱膨㠈処理の有無による差趡はほとん
ど照められなかった。不透明度についてはデンプンパル プ添加量の增加に伴って低下し，各種添加放の添加によ る差異はほとんどなかった(図8)。これはデンプシパル ブ成分が乾燥と共にフィルム化して散乱係数が低下゙する ことによる[3]。このような不透明性の低下は，製紙に 打けるデンプンパルプの利用に対してマイナスとなる。 白色度はデンプン含有量に関保なくはぼ定であった。

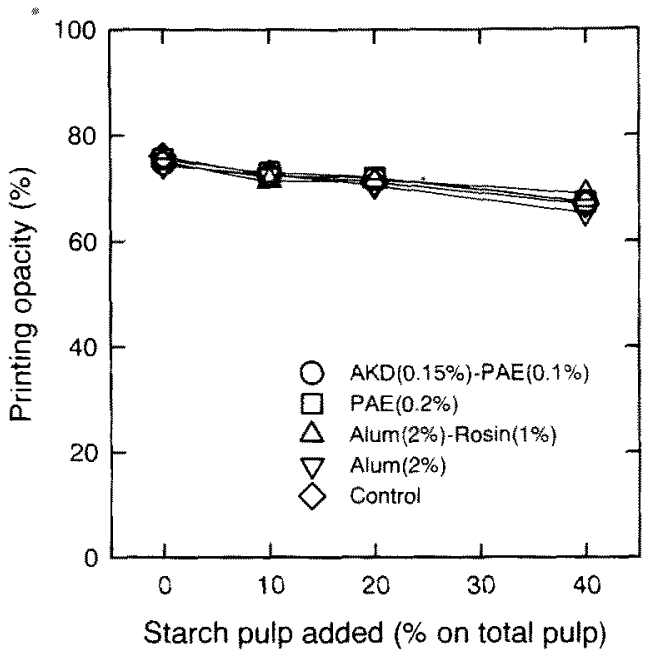

Fig. 8 Opacity of handsheets prepared from HBKP and the original starch pulp with various wet-end additives.

\section{3 サイズ性}

前報では，AKDサイズ剤添加におけるデンプンパルプ 添加量とサイズ度の関係を示し，デンプンパルプ添加量 の增加によってシートのサイズ度が低下寸る傾向があっ た、本報では，エマルジョンロジンサイズー硫酸アルミ ニウム系でのサイズ特性の変化を，サイズ敦拉よびアル ミニウムの抄留り量(含有量)に基づてて検討した。

加熱膨潤処理をしていないデンプンパルプAを用いた 埸合の結果を図9に示寸.シート中のロジンサイズ郕含有 量拉よびアルミニウム含有量は一定であるにもかかから ず，サイズ度はデンプンパルプAの添加量の增加に伴い 低下した，国10の加熱膨潤処理したデンプンパルプB 用いた場合には，10\%添加でも急激なサイズ度の低下が 認められた。この場合も，サイズ刘およびアルミニウム の紙中含有量は、デンプンパルプBの添加量に对して一 定であった，デンブンパルプの添加によってシート密度 がやや增加し、シートの厚さがやや低下寸る候向を示し たが、サイズ度の著しい低下を䫓明できるほどではなか った。したがって：シートの乾燥過程でデンプンパルプ 成分がフイルム化して部分的に維間結合定補強子る効 


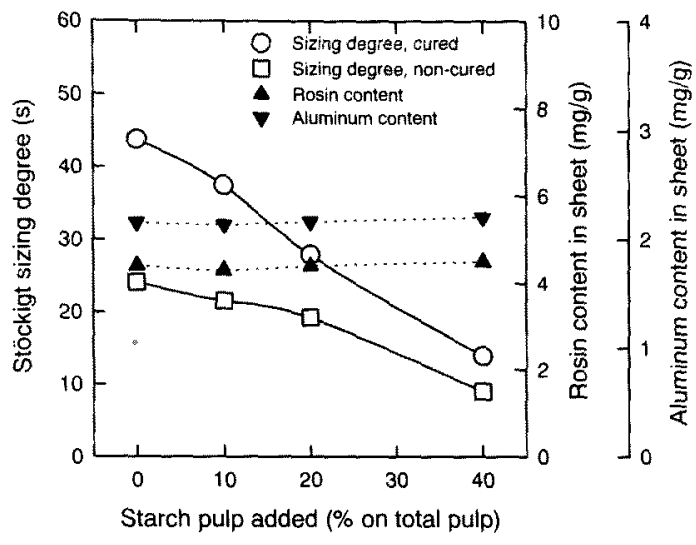

Fig. 9 Sizing degrees and rosin and aluminum contents of handsheets prepared from HBKP and the original starch pulp with aluminum sulfate ( $2 \%$ on total pulp) and emulsion rosin size ( $1 \%$ on total pulp) at $\mathrm{pH}=6$.

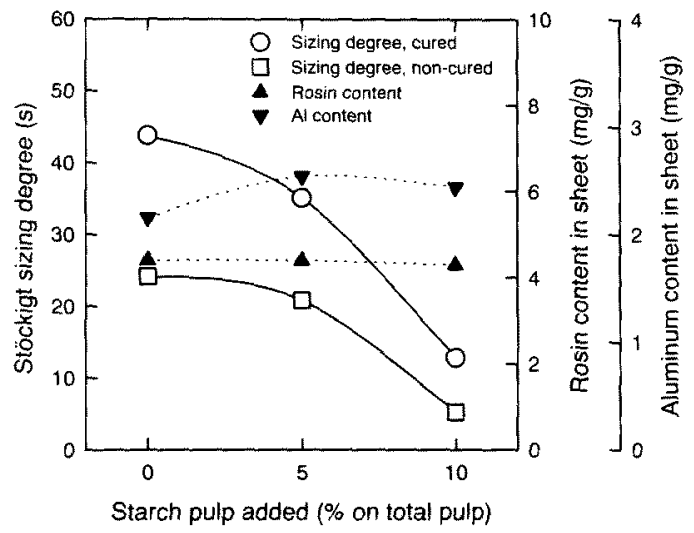

Fig.10 Sizing degrees and rosin and aluminum contents of handsheets prepared from HBKP and the swollen starch pulp with aluminum sulfate ( $2 \%$ on total pulp) and emulsion rosin size $(1 \%$ on total pulp) at $\mathrm{pH}=6$.

果を表すような状況が, AKD，ロジンサイズどちらの場 合でも，サイズ性発現にはマイナスに作用することを示 している、デンプンパルプの添加によって，サイズ澈成 分がシート中のパルブ絏維表面に存在せず，フィルム化 したデンプンによって覆われてしまっている可能性，あ るいは，親水性のフィルム化したデンプン部分が水の浸 透を促進してしまっている可能性もあるが，詳細は不明 である。これらのサイズ性の低下はデンプンパルプ添加 による欠点の一つとなる。

一方，図9，100結果は，サイズ削成分や歩留り堉のシ
一トへの歩留り量は, デンプンパルプの添加によって影 響されないことを示している。

\section{4 加熱劣化特性}

図11，12にAKDとPAEを添加したデンプンパルプ含有 シートの加熱䞘理後の耐折強さを示す，差はわずかであ るが、いずれも 7 日間の加熱処理により, 耐折強さが低 下寸る䝨向を示した．しかし、特に加熱膨潤処理したデ ンプンパルプBと,PAE0.1\%の添加は耐折強さを著しく

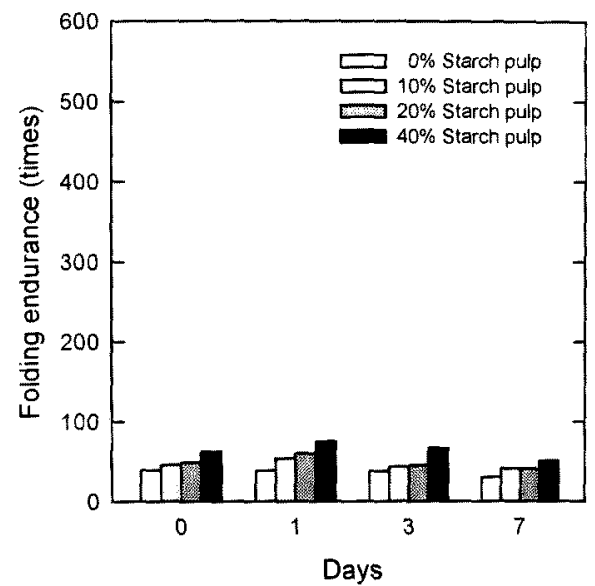

Fig.11 Folding endurance of handsheets after heating at $105^{\circ} \mathrm{C}$ for 0.7 days. The handsheets were prepared from HBKP and the original starch pulp with AKD ( $0.15 \%$ on total pulp) and PAE $(0.1 \%$ on total pulp).

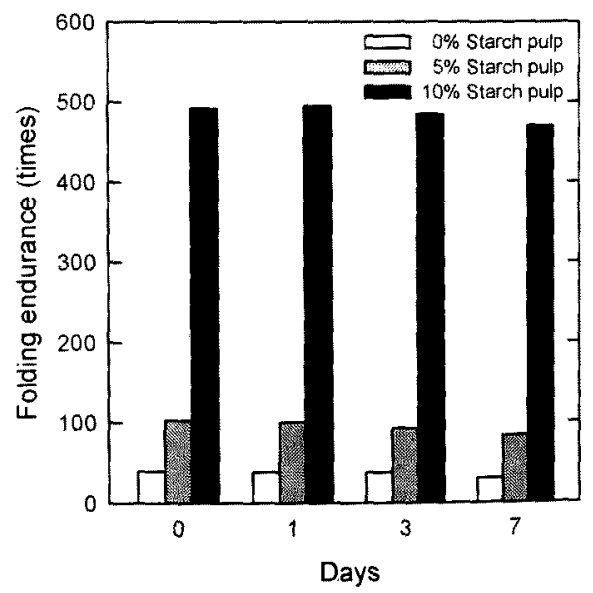

Fig.12 Folding endurance of handsheets after heating at $105^{\circ} \mathrm{C}$ for $0-7$ days. The handsheets were prepared from HBKP and the swollen starch pulp with AKD $(0.15 \%$ on total pulp) and PAE $10.1 \%$ on total pulp). 


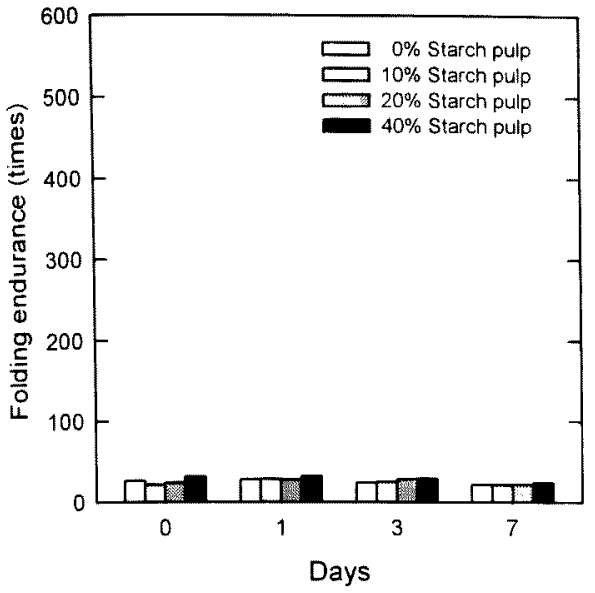

Fig.13 Folding endurance of handsheets after heating at $105^{\circ} \mathrm{C}$ for 0.7 days. The handsheets were prepared from HBKP and the original starch pulp with aluminum sulfate ( $2 \%$ on total pulp) and emulsion rosin size ( $1 \%$ on total pulp).

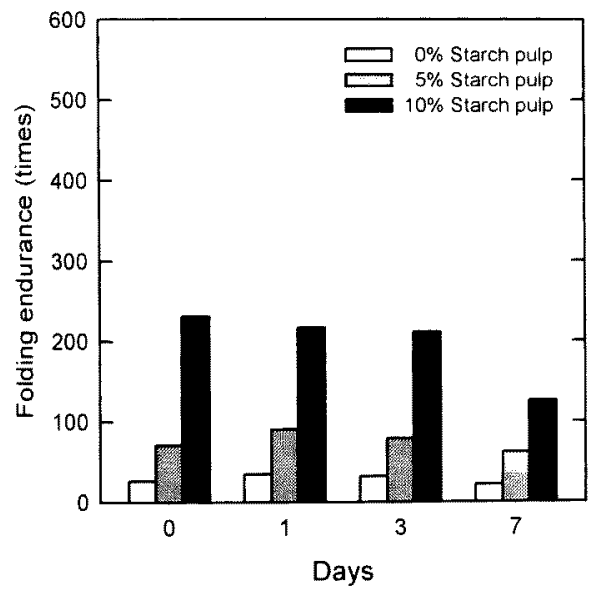

Fig.14 Folding endurance of handsheets after heating at $105^{\circ} \mathrm{C}$ for $0-7$ days. The handsheets were prepared from HBKP and the swollen starch pulp with aluminum sulfate ( $2 \%$ on total pulp) and emulsion rosin size ( $1 \%$ on total pulp).

曾加させる効果があるため，7 日間の加熱劣化処理でも 耐折強さの絶対值は高い值を維持していた(図12).105 ${ }^{\circ} \mathrm{C}$ の加熱劣化処理を行った乾燥器内は，相対湿度はほほ 0 である．したがって，絶乾状態での加熱処理でもデンプ 珹分は脆化性を示さず，その後の調湿処理によってあ る程度柔軟性を維持していることを示唆している。

エマルジョンロジンサイズー硫酸アルミニウム添加系 デンプンパルプ含有シートの加熱処理後の酎折強さを园
13，14に示す，加熱膨潤処理をしていないデンブンパル プAを用いた場合は，全体的に耐折強さが低く，加熱劣 化処理後も值の変化は少なかった，加熱膨潤処理したデ ンプンパルプBを10\%添加した場合は，耐折回数の值が 増加するため，7 日間加熱劣化処理後の耐折強さは低下 したが、耐折回数の值は100回を越えていた。しかし，AKDPAE系に比べると，ロジンと硫酸アルミニウムを添加し た場合の耐折回数は半分以下の值である，したがって， デンプンバルプ B とPAEの相乗効果による耐折強さの著 しい向上は，加熱劣化処理後でも維持された。

\section{4. 結 論}

フレーク状のデンプンパルプを木材パルプの一部代替 として，各種のウェットエンド添加剤と共に作製した手 寸きシートの特性を把握することができた。加熱膨潤処 理を経ることによりデンプンパルブ成分は，シート内の 木材パルプの䋞維間結合を部分的に補強する効果を持ち， 添加量の増加により，耐折強さは著しく増大した，PAE の添加は耐折強さに对して相乗的な向上作用を示した。

したがって，ウェットエンド添加戍により，デンプンパ ルプ含有紙の物性をさらに制御できる。一方，サイズ性， 不透明度は減少した，加熱膨潤処理したデンプンパルプ 添加による耐折強さの增加が顕著であるため, 加熱劣化 処理後の耐折強さも一定の值以上を維持することができ た，今後の検討課題として、デンプンパルプの熱水，ア ルカリ，微生物等に対する安定性の向上が挙げら机る。

\section{謝辞}

本研究は文部省科学研究費補助金 (基盤研究(B) (2)) に よる研究“デンプンの韯維化技術の構築”(課題番号07556126, 研究代表者：磯具 明, 平成7 8年)の一部として実施し た。

\section{文献}

1. J. R. Hart, D. W. Lare and J. J.Nault (National Starch Inc.), U. S. Pat. 4205025 (1980)

2. J. R. Hart, S. G. Guergens and W. E. McCormack (National Starch Inc.), U. S. Pat. 4340442 (1982).

3. K. Okomori, A. Isogai, J. Yoshizawa and F. Onabe, Nordic Pulp Paper Res. J., 9, 237 (1994).

4. TAPPI Test Methods, T205 sp-95(1996).

5. TAPPI Test Methods, T494 om-88(1996).

6. TAPPI Test Methods, T511 om-96(1996).

7. JIS試験法, P 8135 (1979).

8. TAPPI Test Methods, T519 om-96(1996).

9. TAPPI Test Methods, T452 om-92(1996). 
10. JIS 試験法, P 8122 (1979).

11. T. Kitaoka, A. Isogai and F. Onabe, Nordic Pulp Paper Res. J., 10, 253(1995).

12. A. Isogai, "Effect of Cationic Polymer Addition on Retention of Alkylketene Dimer", J. Pulp Paper Sci., 23[6], in press (1997).
13. M. Kato, A. Isogai and F. Onabe, unpublished data.

14. A. Isogai, F. Onabe and M. Usuda, Sen'i Gakkaishi, 48, 281 (1992).

15. A. Isogai, Sen'i Gakkaishi, 57, 96 (1997). 